\title{
ANALISIS HUBUNGAN KARAKTERISTIK OSEANOGRAFI DAN HASIL TANGKAPAN YELLOWFIN TUNA (Thunnus albacares) DI PERAIRAN LAUT BANDA
}

\author{
Umar Tangke*; Achmar Mallawa**; Mukti Zainuddin** \\ *Staf Pengajar Faperta UMMU-Ternate, e-mail: khakafart@yahoo.com \\ **Staf Pengajar FIKP UNHAS-Makassar
}

\begin{abstract}
Abstrak
Penelitian dimulai dari bulan Januari - Mei 2011 bertujuan untuk menganalisis hubungan antara faktor oseanogrfi dan hasil tangkapan yellowfin tuna di perairan laut Banda. Data hasil pengamatan dianalisis dengan menggunakan regresi linier berganda untuk melihat pengaruh parameter oseanografi secara bersama-sama dan secara individual terhadap hasil tangkapan yellowfin tuna. Hasil analisis regresi berganda diketahui bahwa dari lima parameter oseanografi secara bersama-sama berpengaruh nyata terhadap hasil tangkapan yellowfin tuna ini dapat dilihat pada hasil Uji $F$ dengan nilai signifikansi $0.000<0.01$, dan $F_{\text {hitung }}$ lebih besar dari $F_{\text {tabel }}(8.23>2.44)$, Hasil uji $t$ menunjukan bahwa secara individual terdapat tiga dari lima faktor Oseanografi yang berpengaruh nyata terhadap hasil tangkapan ikan yellowfin tuna, diantaranya suhu permukaan laut $(S P L)$, kedalaman dan kecepatan arus.
\end{abstract}

\section{Kata Kunci: Yellowfin tuna, Laut Banda, Sistem informasi Geografis}

\section{PENDAHULUAN}

\subsection{Latar Belakang}

Tuna sirip kuning/yellowfin tuna (Thunnus albacares) atau lebih dikenal dengan nama madidihang adalah salah satu spesies Family Scombridae dan merupakan salah satu komoditi ekspor perikanan tuna yang paling utama di Indonesia selain tuna mata besar (Thunnus obesus) dan tuna sirip biru selatan (Thunnus maccoyi). Berdasarkan data Dinas Perikanan Provinsi Maluku (2008) dilaporkan bahwa pada tahun 2007 tuna yang diekspor dalam bentuk segar dan beku sekitar 9.007 ton dengan tujuan Jepang, Amerika, Inggris dan lain-lain.

Laut Banda merupakan daerah penangkapan tuna yang sangat potensial di Provinsi Maluku. Pemanfaatan sumberdaya tuna di laut Banda dari tahun ke tahun cenderung terus meningkat. Hal ini terindikasi dengan semakin bertambahnya jumlah armada yang beroperasi di wilayah perairan tersebut dan jumlah peningkatan hasil tangkapan yang meningkat dari tahun 20062007 sebesar 59.98 ton/tahun atau sekitar $35 \%$ (DKP Provinsi Maluku, 2008).
Salah satu upaya untuk optimalisasi pemanfaatan perikanan tuna di perairan laut Banda adalah penangkapan dengan menggunakan alat tangkap Hand line dimana nelayan sangat bergantung pada penentuan daerah penangkapan ikan sebelum dilakukan operasi penangkapan. Penentuan daerah penangkapan ini merupakan salah satu faktor penentu keberhasilan usaha penangkapan ikan (Muklis $d k k, 2009$ ). Pada umunya nelayan menentukan daerah penangkapan ikan berdasarkan insting dan pengalaman lapangan sehingga kurang efektif karena tingkat ketidakpastian cukup tinggi.

Daerah Penangkapan ikan sangat tergantung pada faktor-faktor lingkungan. Kelimpahannya ditentukan oleh kondisi optimal perairan yang mendukung bagi kehidupannya. Pola distribusi suhu permukaan laut (SPL) dapat digunakan untuk mengidentifikasi parameterparameter laut seperti arus, upwelling, dan front (Pralebda dan Suyuti, 1983). Gower (1972), menjelaskan bahwa produksi ikan juga berhubungan dengan konsentrasi pigmen-pigmen klorofil perairan.

Prediksi daerah penangkapan yang potensial untuk penangkapan ikan dapat 
dilakukan melalui pengkajian parameterparameter oseanografi yang berhubungan dengan keberadaan ikan itu sendiri. Oleh karena itu perlu dilakukan suatu penelitian tentang analisis hubungan karakteristik oseanografi dan hasil tangkapan yellowfin tuna di perairan Laut dan output yang diperoleh diharapkan dapat digunakan sebagai sumber dan acuan untuk pengelolaan dan pemanfaatan sumberdaya perikanan khususnya yellowfin tuna yang lebih optimal.

\subsection{Tujuan dan Manfaat Penelitian}

Penelitian ini bertujuan untuk menganalisis hubungan antara faktor oseanogrfi dan hasil tangkapan yellowfin tuna di perairan laut Banda.

Manfaat dari penelitian ini adalah sebagai bahan informasi awal dalam membantu nelayan dalam melakukan efisiensi operasi dan efektifitas penangkapan sebab dengan diketahuinya daerah prakiraan penangkapan ikan maka waktu yang dibutuhkan untuk mencari daerah penangkapan menjadi lebih singkat serta sebagai bahan informasi kepada nelayan, pemerintah dan pihak swasta dalam membuat rencana strategi yang tepat mengenai pengembangan dan pemanfaatan tuna hand line.

\section{METODE PENELITIAN}

\subsection{Waktu dan Tempat}

Penelitian ini telah dilaksanakan selama Januari - Mei 2011. Pengamatan dan Pengambilan data lapangan dilakukan pada saat operasi penangkapan dengan lokasi di laut Banda dengan Fishing Base berada pada di desa Ureng Kec. Leihitu Kab. Maluku Tengah Prov. Maluku, data citra satelit didownload di LAPAN Pare-Pare Prov. Sulawesi Selatan.

\subsection{Alat dan Bahan}

Alat dan bahan yang digunakan dalam penelitian ini adalah : Alat Tangkap Hand Line, Global Position System (GPS), Handrefraktometer, Thermometer, Stop Watch, Layangan arus, Kamera digital, Alat tulis menulis, Komputer, Data Citra Satelit (Suhu dan Klorofil-a) dari satelit AQUA/MODIS, data kedalaman dari Etopo1, ArcView 3.3, ENVI 4.3, SPSS 12, MS Office 2003 dan Kuisioner.

\subsection{Metode Penelitian}

\subsubsection{Pengumpulan Data}

Data primer dikumpulkan dari kapal Tuna Hand line (long boat), yang meliputi data hasil tangkapan, posisi daerah penangkapan, unit penangkapan yellowfin tuna, kegiatan operasi penangkapan, daerah penangkapan.

Data sekunder data citra (SPL dan Klorofil-a) satelit dari satelit AQUA/MODIS dan didownload dari NASA data base (oceancolor. gsfc.nasagov). Data kedalaman perairan di download dari etopo1 global relief (http://www.ngdc.noaa.gov/mgb).

\subsubsection{Prosedur Penelitian}

Stasiun pengambilan sampel di tentukan dengan menggunakan GPS (Global Position System) yang diplot dengan peta digital perairan Laut Banda. Penentuan satsiun berdasarkan titik posisi daerah penangkapan nelayan setempat dengan tingkat keterwakilan dari areal yang disurvei bersamaan dengan proses operasi penangkapan. Pengambilan data dilakukan pada saat operasi penangkapan dengan melakukan pencatatan jumlah hasil tangkapan pada masingmasing jenis umpan serta pengukuran parameter oseanografi (suhu, klorofil-a, salinitas, kecepatan arus dan Kedalaman). Data Hasil tangkapan diakumulasi dari semua kapal yang melakukan operasi penangkapan pada waktu dan hari yang sama dan pada daerah penangkapan yang sama, data hasil tangkapan ditimbang dan dicatat total beratnya dalam kilogram $(\mathrm{kg})$.

\subsection{Analisis Kondisi Oseanografi Dan Hasil Tangkapan}

Pengambilan data umumnya dilakukan dilapangan dengan berbagai faktor yang sulit dikontrol yang dapat menyebabkan terjadinya bias pada data pengukuran, maka untuk analisis data di gunakan tingkat kepercayaan $90 \%$. Data kondisi oseanografi dan data hasil tangkapan dianalisis menggunakan metode statistik sebagai berikut :

1) Analisis Regresi Berganda

persamaan matematika di pakai untuk analisis data hasil tangkapan yellowfin tuna sebagai nilai variabel bebas $(y)$ dengan variabel tak bebas suhu $\left(x_{1}\right)$, klorofil-a $\left(x_{2}\right)$, kedalaman $\left(x_{3}\right)$, salinitas $\left(x_{4}\right)$ dan kecepatan arus $\left(x_{5}\right)$, adalah :

$\hat{y}=a+b_{1} x_{1}+b_{2} x_{2}+\cdots+b_{5} x_{5}+e \ldots \ldots(1)$

Dengan $a$ (koefisien potongan), $b_{1}$ (koefisien regresi SPL), $b_{2}$ (koefisien regresi klorofil-a) dan $b_{3}$ (koefisien regresi kedalaman), selain itu analisis regresi yang baik harus memenuhi beberapa syarat antara lain :

\subsubsection{Uji Normalitas Data}


Ada dua cara untuk melihat kenormalan data yaitu secara visual dan dengan uji statistik. Uji normalitas data dengan uji statistik digunakan Lilliefors Test (Kolmogorov-Smimov Test). Hipotesis yang digunakan yaitu $\mathrm{H}_{\mathrm{o}}$ : data berdistribusi normal, $\mathrm{H}_{1}$ : data tidak berdistribusi normal. Jika nilai signifikan lebih besar 0,1 maka hipotesis tentang data berdistribusi normal akan diterima (gagal tolak $\mathrm{H}_{\mathrm{o}}$ ), dan jika lebih kecil 0,1 maka data tidak berdistribusi normal (terima $\mathrm{H}_{1}$ ).

\subsubsection{Uji Multikolinieritas}

Model regresi yang baik mensyaratkan tidak adanya masalah multikolinieritas.

Untuk melihat ada tidaknya multikolinieritas yaitu dengan melihat nilai Tolerance dan VIF. Semakin kecil nilai tolerance dan semakin besar nilai VIF maka semakin mendekati terjadinya masalah multikolinieritas.

\subsubsection{Analisis Varians (Uji F)}

Pengujian ini dilakukan untuk menguji pengaruh variabel bebas (independent) secara bersama terhadap variabel tak bebas (dependent).

\subsubsection{Analisis Koefisien Regresi (Uji t)}

Uji t dilakukan untuk melihat pengaruh masingmasing variabel bebas (independent) terhadap variabel tak bebas (dependent) sehingga diperoleh model regresi terbaik.

\section{HASIL DAN PEMBAHASAN}

\subsection{Keadaan Umum Daerah Penangkapan}

Daerah penangkapan yellowfin tuna di laut Banda terletak antara pulau Ambon, pulau Buru, pulau Manipa, pulau kelang dan pulau Seram dengan batas utara pada koordinat $3^{\circ} 24^{\prime}$ $12^{\prime \prime}$ LS, bagian selatan pada kordinat $4^{\circ} 14^{\prime} 3$ " LS, Bagian barat pada koordinat $127^{\circ} 51^{\prime} 43^{\prime \prime}$ BT sedangkang bagian timur pada koordinat $126^{\circ} 41^{\prime}$ 12 " BT.

Daerah penangkapan terdekat selama penelitian berjarak $5.95 \mathrm{~km}$ dari fishing base tepatnya berada pada posisi $127^{\circ} 52^{\prime} 3$ " BT dan $3^{\circ} 39^{\prime} 19^{\prime \prime} \mathrm{LS}$, sedangkan lokasi terjauh berjarak 145,19 km dari fishing base tepatnya berada di selatan pulau Buru dekat pulau Ambalau dengan posisi $126^{\circ} 41^{\prime} 12^{\prime \prime}$ dan $4^{\circ} 7$ ' 19" LS. Posisi daerah penangkapan pada Gambar 1. di petakan berdasarkan titik koordinat yang diperoleh dilapangan dan dianalisis dengan menggunakan model analisis spasial dan IDW, sehingga dapat diketahui bahwa operasi penangkapan dengan menggunakan alat tangkap hand line di perairan laut Banda umumnya berada diperairan lepas pantai (off shore). Hal ini sesuai dengan pendapat Uktolseja et al., (1988) dalam Tadjudah (2005) bahwa ikan madidihang atau yellowfin tuna adalah jenis ikan epipelgis dan oseanis yang menyukai perairan diatas dan di bawah termoklin.

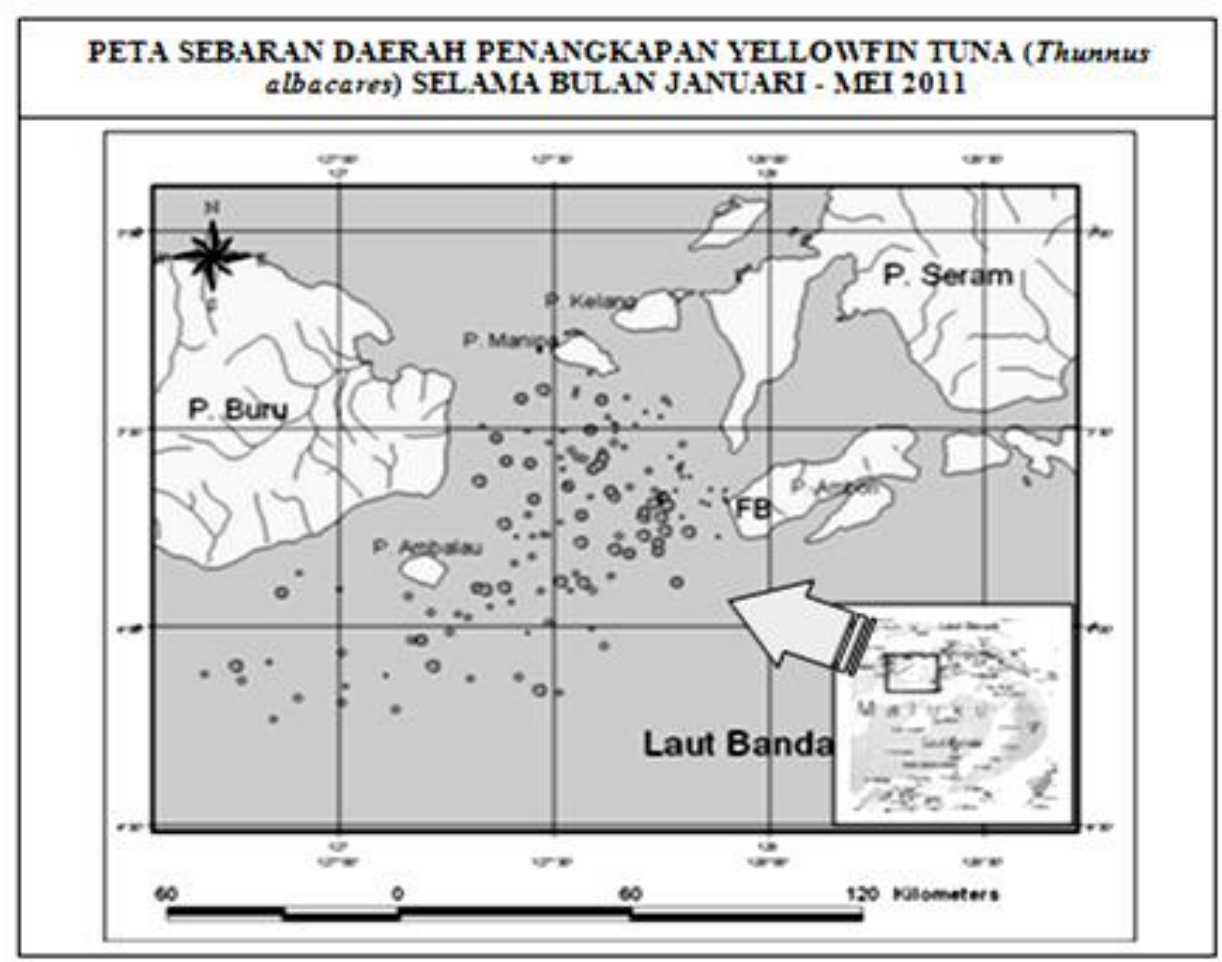

Gambar 1. Peta Distribusi Daerah Penangkapan Yellowfin Tuna Selama Penelitian (Januari - Mei 2011). 


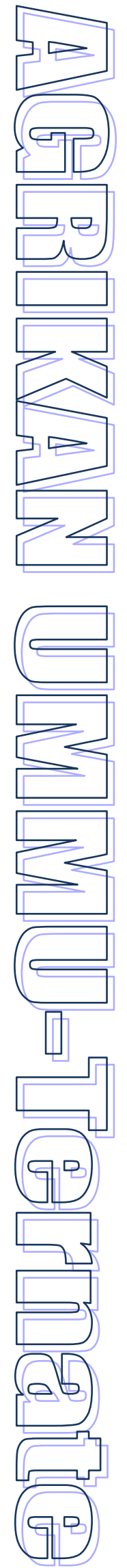

\subsection{Deskripsi Alat Tangkap Hand Line}

Kapal tuna hand line atau lebih dengan nama long boat adalah jenis kapal ikan yang dioperasikan untuk menangkap ikan tuna (Thunnus spp), konstruksi jenis kapal ini terbuat dari bahan kayu dan fiber glass dengan penggerak mesin out board yang berkekuatan antara 15 - $40 \mathrm{HP} / \mathrm{PK}$ dan kecepatan antara 5 - 7 Knot, kapal long boat di lengkapi dengan palkah yang kedap udara dan bak penampung umpan hidup, dengan daya muat kapal antara 0.5 - 3 GT (Gross Tonage). Disain utama kapal long boat adalah Panjang (L) 7 - 10 m, Lebar (B) 0.7 - 0.9 m, Tinggi (H) 0.9 - 1 m dan Draft Kapal (d) 0.3 $0.4 \mathrm{~m}$.

Alat tangkap tuna hand line terdiri dari main line, mata pancing, kili-kili, pemberat, wire , float/pelampung dan alat bantu penangkapan adalah gelang, ganco, tombak dan balok pemukul. Umpan yang dipakai untuk menangkap yellowfin tuna adalah jenis umpan hidup dan umpan buatan, umpan hidup diantaranya adalah ikan terbang (Hirundichthys oxycephalus), ikan layang (Decapterus sp), ikan trigger (Odunnus niger) dan cumi (Loligo spp), sedangkan umpan buatan antara lain kepala sendok makan yang diberi mata pancing, umpan buatan menyerupai cumi, ikan terbang dan ikan layang, umpan buatan ini terbuat dari selang air sebagai tubuh ikan dan sirip serta ekor terbuat dari ban dalam bekas dan gaya lambat yang terbuat dari kertas bening berbentuk segi tiga dengan bagian ekor yang panjang kemudian pada bagian tengahnya di beri kertas berwarna biru, jika ikan tuna lebih cenderung untuk memakan ikan layang, warnawarni jika ikan tuna cenderung memakan umpan cumi serta kertas bening murni jika ikan tuna cenderung memakan umpan ikan komo.

\subsection{Metode Penangkapan}

Operasi penangkapan ikan tuna yang dilakukan oleh nelayan di desa Ureng efektif dilakukan antara jam 08.00 - 15.00 WIT, dimana dimulai dengan pencarian daerah penangkapan atau fishing ground. Setelah daerah penangkapan ditentukan maka nelayan mempersiakan alat tangkap dengan urutan sebagai berikut ; 1) Penyiapan batu (pemberat) yang diikat dengan daun kelapa (samira) dengan jumlah antara 10 20 buah; 2) main line dilepas dari penggulung dengan panjang sekitar 30 - 60 meter, kemudian pemasangan kail pada pada ujung tasi/main line yang dihubungkan dengan wire; 3) pemasangan umpan pada kail, untuk umpan hidup dikaitkan pada bagian punggung dari ikan umpan; 4) batu pemberat di kait bersama dengan umpan pada kail kemudian diturunkan bersama dengan umpan dengan kedalaman \pm 20 - 50 meter atau sampai mencapai gerombolan ikan tuna; 5) main line di hentakan untuk melepaskan batu pemberat dari umpan; 6) jika ikan telah memakan umpan maka proses selanjutnya adalah alat tangkap dinaikan dengan cara main line di tarik keatas kapal tangkap proses ini biasanya berjalan 20 - 30 jika nelayan menggunakan gelang; 7) jika ikan hasil tangkapan telah berhasil ditarik hingga mencapai pinggir kapal maka ikan tersebut diganco pada bagian pipi/operculum kemudian di pukul sampai mati dengan pemukul yang sudah di siapkan, kemudian hasil tangkapan tersebut dinaikan ke atas kapal; 8) hasil tangkapan segara di loin/fillet jika sudah naik ke kapal. Hal ini dilakukan untuk menjaga agar mutu ikan tersebut tidak turun sehingga harga jual ikan tersebut tetap tinggi.

\subsection{Hasil Tangkapan Yellowfin tuna}

Produksi hasil tangkapan yellowfin tuna dari bulan Januari sampai Maret 2011 menunjukan trend menurun, dimana produksi pada bulan Januari $9.853,05 \mathrm{~kg}$ turun menjadi 9.389,24 kg pada bulan Februari serta 5.657,65 $\mathrm{kg}$ pada bulan Maret. Pada bulan April produksi meningkat menjadi $11.871,8 \mathrm{~kg}$ dan pada bulan Mei turun dengan total produksi adalah 762,48 $\mathrm{kg}$ (Gambar 2), rendahnya produksi pada bulan Mei ini jumlah trip operasi penangkapan yang sedikit diakibatkan oleh kondisi fisik perairan yang bergelombang.

Berdasarkan rata-rata hasil tangkapan bulanan yellowfin tuna dari bulan Januari sampai dengan Mei 2011 terlihat bahwa musim tangkapan mencapai puncak pada bulan April 2011, hal ini sesuai dengan pendapat Uktolseja $e t$ al. (1991) dalam Nugraha 2009, bahwa potensi yellowfin tuna pada bulan April untuk daerah penangkapan laut Banda cukup padat.

\subsection{Fluktuasi Parameter Oseanografi dan Hasil Tangkapan Yellowfin tuna}

Karakateristik parameter oseanografi di perairan laut Banda mengalami fluktuasi yang berbeda-beda selama pelaksanaan penelitan. Hal ini dapat dilihat pada fluktuasi harian parameter oseanografi selama penelitian pada bulan Januari sampai Mei 2009. Fluktuasi parameter oseanografi ini diantaranya : 


\subsubsection{Suhu Permukaan Laut (SPL)}

SPL bulanan pada daerah penelitian berkisar antara $25.7-30,2{ }^{\circ} \mathrm{C}$. Nilai SPL mengalami fluktuasi seperti terlihat pada Gambar 3, Berdasarkan grafik fluktuasi SPL dan hasil tangkapan, dapat dilihat bahwa hasil tangkapan tertinggi bulan Januari dengan kisaran suhu $26-28{ }^{\circ} \mathrm{C}$, dengan jumlah hasil tangkapan
540 - $650 \mathrm{~kg}$, bulan Februari pada kisaran suhu $26-29{ }^{\circ} \mathrm{C}$ dan jumlah hasil tangkapan 500 - 650 $\mathrm{kg}$, bulan Maret pada suhu $29.5^{\circ} \mathrm{C}$ dan 29.100 ${ }^{\circ} \mathrm{C}$, dengan hasil tangkapan $653.560 \mathrm{~kg}$ dan 537 $\mathrm{kg}$, bulan April pada kisaran suhu $26-29.5^{\circ} \mathrm{C}$, Bulan Mei umumnya hasil tangkapan berada dibawah kisaran $200 \mathrm{~kg}$ dengan kisaran suhu antara $25-28^{\circ} \mathrm{C}$. secara umum dapat dilihat bahwa nilai kisaran suhu ini masih berada dalam kisaran suhu yang disukai yellowfin tuna yaitu $18-31^{\circ} \mathrm{C}$ (FAO, 2003).

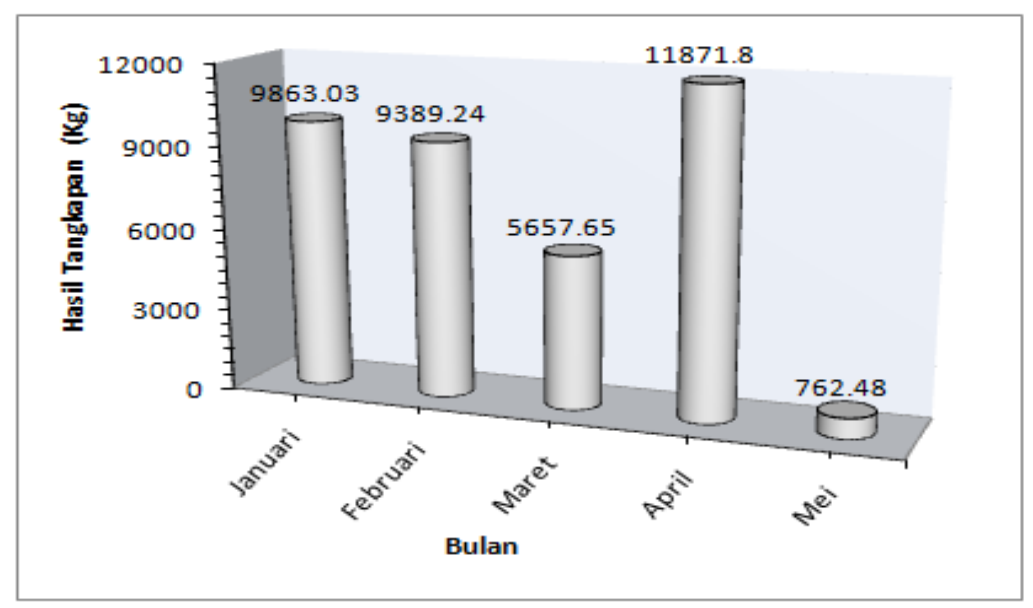

Gambar 2. Hasil Tangkapan Yellowfin Tuna Selama Januari - Mei 2011

\subsubsection{Klorofil-a}

Nilai konsentrasi klorofil-a pada lapisan permukaan laut Banda selama peneliatan berkisar antara $0.002 \mathrm{mg} / \mathrm{m}^{3}$ sampai dengan $0.668 \mathrm{mg} / \mathrm{m}^{3}$ dengan nilai rata-rata sebaran kandungan klorofil-a adalah $0.119 \mathrm{mg} / \mathrm{m}^{3}$. Gambar 4, dapat dilihat bahwa pada bulan Januari sampai dengan Maret hasil tangkapan tertinggi berada pada kisaran konsentrasi klorofil-a dibawah 0,20 $\mathrm{mg} / \mathrm{m}^{3}$, sedangkan pada bulan April umumnya hasil tangkapan tertinggi berada pada kisaran diatas $0.2 \mathrm{mg} / \mathrm{m}^{3}$, bulan Mei hasil tangkapan umumnya berada dibawah $0.2 \mathrm{mg} / \mathrm{m}^{3}$ dan hasil tangkapan relatif kecil. Secara umumn nilai kisaran klorofil-a pada laut Banda sebagian besar berada pada kisaran nilai $0.20 \mathrm{mg} / \mathrm{m}^{3}$, dengan rata-rata nilai $0.119 \mathrm{mg} / \mathrm{m}^{3}$, nilai ini sesuai dengan hasil penelitian Syah (2009), bahwa konsentrasi klorofil-a selama musim barat dan peralihan I diperairan laut Banda pada lapisan permukaan (kedalaman $0-20 \mathrm{~m}$ ) umumnya berada dibawah nilai $0.2 \mathrm{mg} / \mathrm{m}^{3}$.

\subsubsection{Kedalaman}

Kedalaman renang tuna dan cakalang bervariasi tergantung dari jenisnya, umumnya tuna dan cakalang tertangkap di kedalaman 0 -
400 meter. Sedangakangkan kedalaman perairan selama penelitian berkisar antara \pm 705.280 5,298.9 m, dimana ini sudah merupakan daerah perairan yang berada di lepas pantai offshore.

Histogram pada Gambar 5, menunjukan pada bulan Januari dan April hasil tangkapan tertinggi berada pada kedalaman diatas $3000 \mathrm{~m}$, sedangkan bulan Februari, Maret dan Mei hasil tangkapan tertinggi berada pada kedalaman antara $2000-4000 \mathrm{~m}$.

\subsubsection{Salinitas}

Model grafik fluktuasi salinitas dan hasil tangkapan yellowfin tuna pada Gambar 6 menunjukan bahwa fluktuasi salinitas di perairan laut Banda selama bulan Januari berada pada kisaran 30,250 - 35.200\% dengan hasil tangkapan tertinggi antara $313.800-669.320 \mathrm{~kg}$, bulan Februari hasil tangkapan tertinggi (542.397 - $559.720 \mathrm{~kg}$ ) berada pada kisaran salinitas 32.900 - $33.450 \mathrm{~kg}$, bulan Maret hasil tangkapan tertinggi (537.100 dan $653.560 \mathrm{~kg}$ ) terdapat pada kisaran salinitas antara 32.400 dan $35.100 \%$ o, bulan April hasil tangkapan tertinggi (442.120 $669.930 \mathrm{~kg}$ ) pada nilai kisaran salinitas antara 32.700 - $34.200 \%$, dan bulan Mei umumnya nilai kisaran salinitas antara $29.700-33.700 \%$ 
dengan jumlah hasil tangkapan relatif berada dibawah $200 \mathrm{~kg}$. Secara umum dapat dilihat pada grafik fluktuasi harian salinitas dan hasil tangkapan yellowfin tuna, bahwa tinggi rendahnya fluktuasi harian salinitas tidak membentuk pola tertentu terhadap hasil tangkapan.

\subsubsection{Kecepatan Arus}

Gambar 7 menunjukan fluktuasi harian kecepatan arus dan hasil tangkapan yellowfin tuna, dimana pada bulan januari hasil tangkapan tertinggi $(515.435-669.320 \mathrm{~kg})$ berada pada kisaran nilai kecepatan arus $0.029-0.033 \mathrm{~m} / \mathrm{s}$, bulan Februari $(542.397 \mathrm{~kg}$ dan $559.720 \mathrm{~kg}$ ) pada kecepatan arus $0.021 \mathrm{~m} / \mathrm{s}$ dan $0.030 \mathrm{~m} / \mathrm{s}$, bulan Maret dan April hasil tangkapan tertinggi berada pada kisaran kecepatan arus antara $0.02 \mathrm{~m} / \mathrm{s}$ sampai $0.04 \mathrm{~m} / \mathrm{s}$ dan bulan Mei umumnya hasil tangkapan relatif kecil dengan nilai kisaran kecepatan arus antara $0.01-0.07 \mathrm{~m} / \mathrm{s}$. secara umum dapat dilihat bahwa hasil tangkapan terbaik berada pada kisaran kecapatan arus antara 0.02 sampai $0.04 \mathrm{~m} / \mathrm{s}$, selain itu ada indikasi bahwa jika nilai kecepatan arus lebih besar atau lebih kecil dari nilai kisaran tersebut tadi, maka hasil tangkapan cenderung kecil.

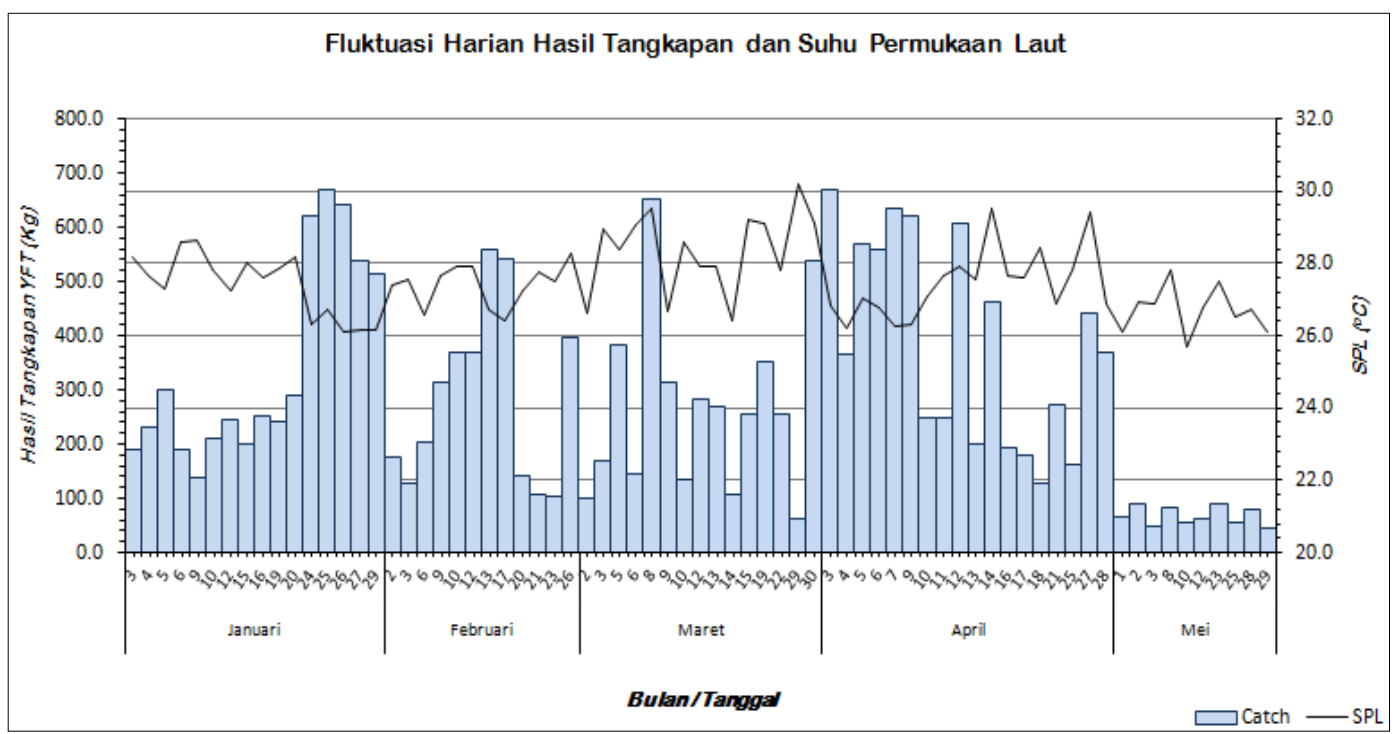

Gambar 3. Fluktuasi Suhu Permukaan Laut (SPL) dan Hasil Tangkapan Yellowfin Tuna Selama Januari - Mei 2011.

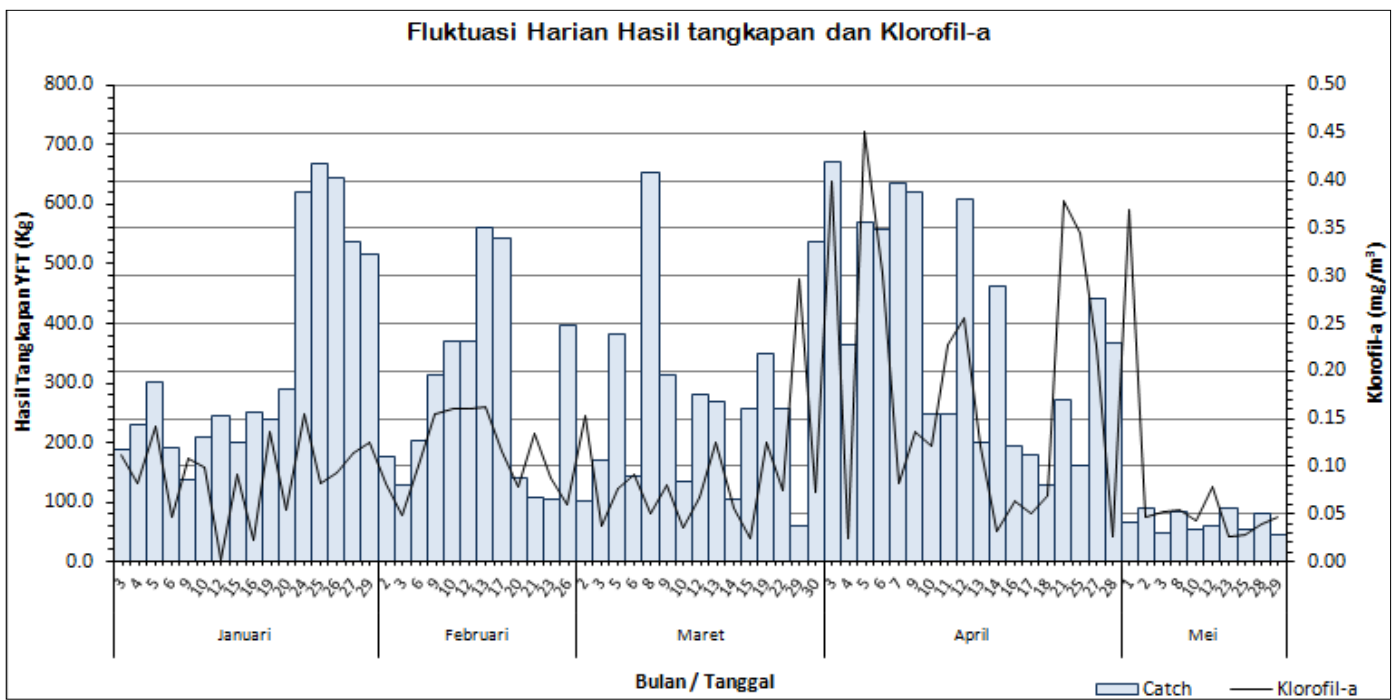

Gambar 4. Fluktuasi Klorofil-a dan Hasil Tangkapan Yellowfin Tuna Selama Januari - Mei 2011. 


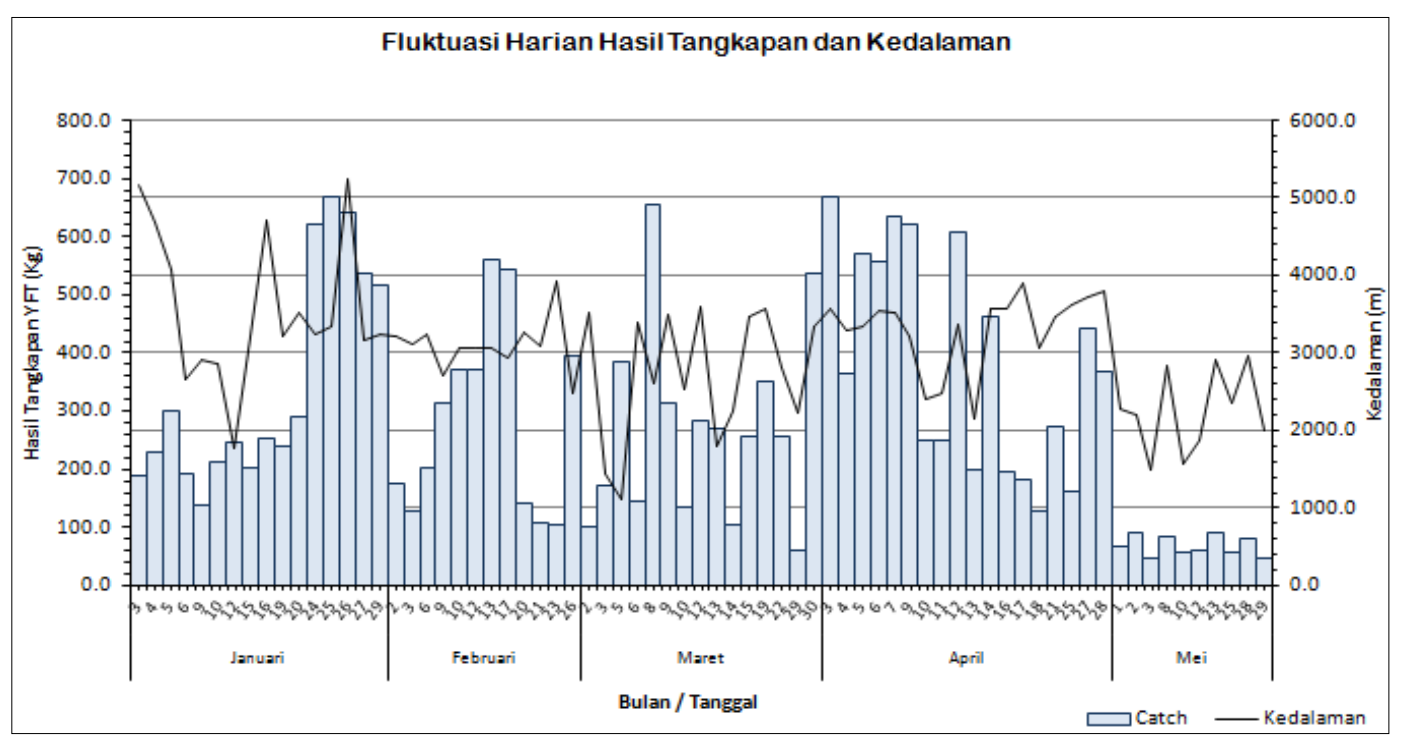

Gambar 5. Fluktuasi Kedalaman dan Hasil Tangkapan Yellowfin Tuna Selama Januari - Mei 2011.

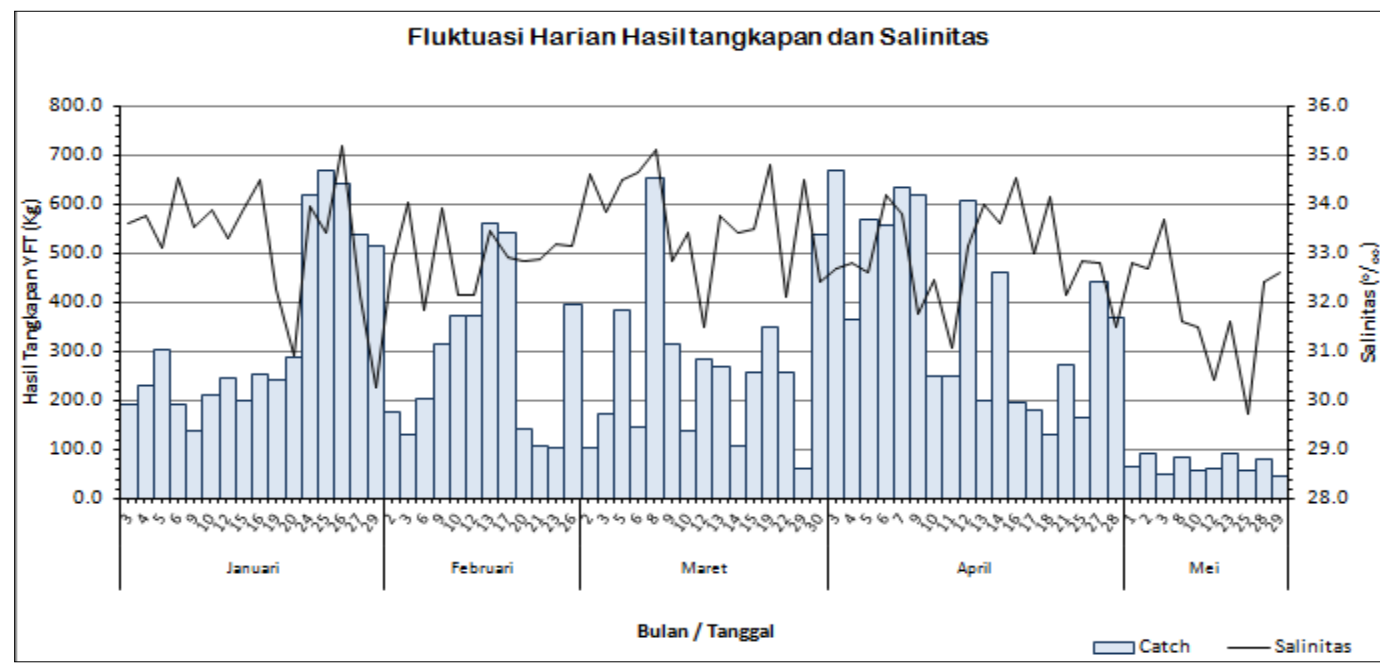

Gambar 6. Fluktuasi Salnitas dan Hasil Tangkapan Yellowfin Tuna selama Januari - Mei 2011.

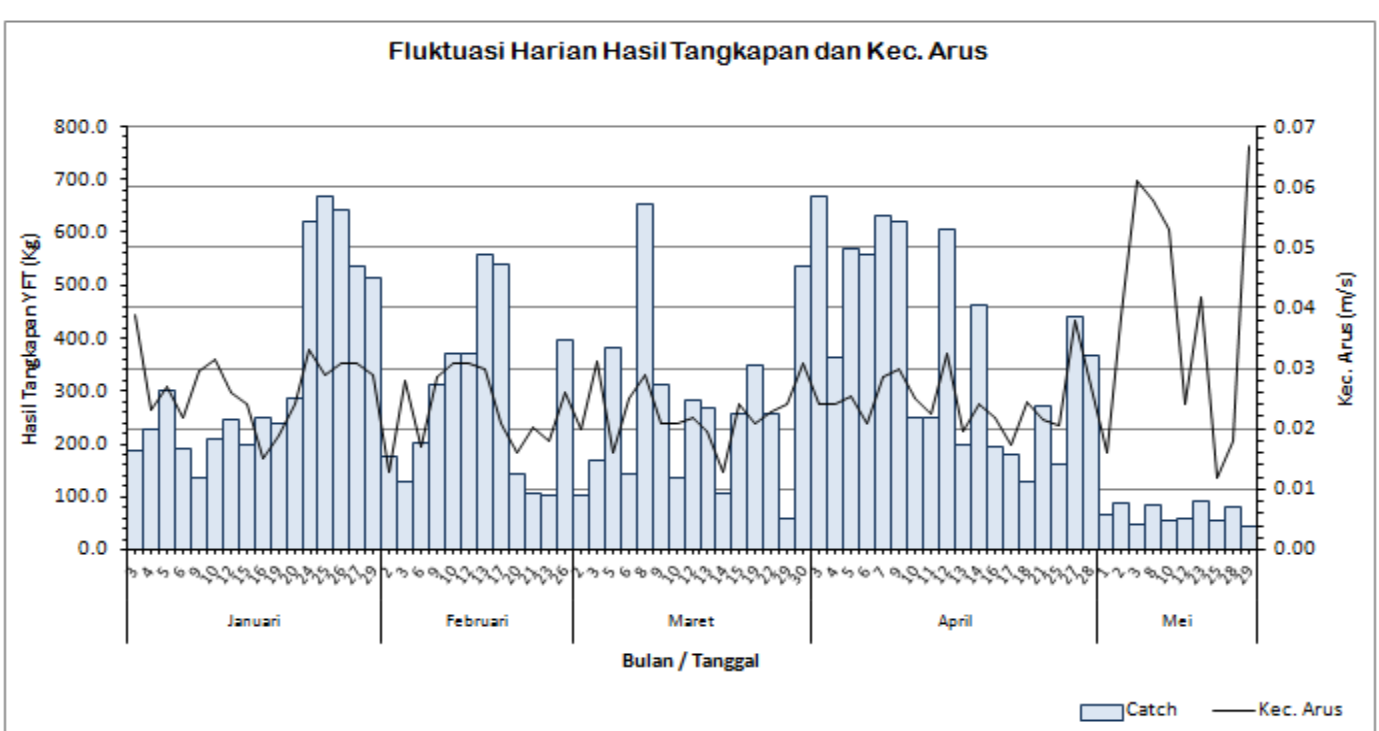

Gambar 7. Fluktuasi Kec. Arus dan Hasil Tangkapan Yellowfin Tuna selama Januari - Mei 2011. 

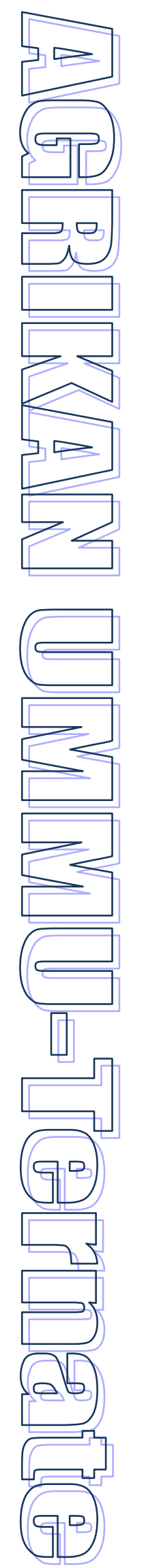

\subsection{Analisis Paramater Oseanografi dan Hasil Tangkapan}

Faktor lingkungan sangat berpengaruh terhadap keberadaan sumberdaya perikanan di suatu perairan, Untuk mengetahui hubungan kondisi oseanografi dan hasil tangkapan tersebut dilakukan analisis parameter oseanografi, diantaranya: parameter Suhu Permukaan Laut/SPL $\left(\mathrm{X}_{1}\right)$, Klorofil-a $\left(\mathrm{X}_{2}\right)$, Kedalaman $\left(\mathrm{X}_{3}\right)$, Salinitas $\left(\mathrm{X}_{4}\right)$, Kecepatan Arus $\left(\mathrm{X}_{5}\right)$ yang dijadikan sebagai variabel bebas sedangkan hasil tangkapan yellowfin tuna (Y) dijadikan sebagai variabel tak bebas. Hubungan kondisi oseanografi dengan hasil tangkapan yellowfin tuna dianalisis dengan regresi linier berganda dimana terdapat beberapa persyaratan yang di penuhi oleh data penelitian untuk mendapatkan model regresi terbaik. Persyaratan tersebut diantaranya adalah uji normalitas dan uji multikolinieritas data.

\subsubsection{Uji Normalitas}

Hasil uji Normalitas dengan menggunakan uji statistik liliefors (Kolmogorov-Smirnov Test) untuk tiap parameter oseanografi, dimana dari kelima paramater tidak satupun data terdistribusi secara normal. Data selanjutnya ditransformasi dengan melogaritmakan semua data, dimana hasil uji normalitas lanjutan diketahui bahwa hanya klorofil-a yang terdistribusi secara normal, sedangkan variabel lainnya masih tidak terdistribusi secara normal. Namun bentuk grafik jumlah hasil tangkapan yellowfin tuna yang dipengaruhi oleh lima parameter oseanografi secara bersama-sama telah mengikuti bentuk distribusi normal dengan bentuk histogram yang hampir sama dengan bentuk distribusi normal. Selain itu pada grafik PP Plots, dapat dilihat bahwa nilai $P P$ terletak disekitar garis diagonal, hal ini mengindikasikan kesamaan antara nilai probabilitas harapan dan probabilitas pengamatan dimana garis diagonal merupakan perpotongan antara garis probabilitas harapan dan probabilitas pengamatan (Lampiran 1).

Data yang tidak berdistribusi normal pada kedua uji normal tersebut diduga terjadi akibat beberapa faktor diantaranya (1) kesalahan manusia (Human error), misalnya teknik pengambilan data; (2) pengaruh faktor alam, misalnya pengukuran salinitas yang bertepatan dengan turunnya hujan; (3) tingkat akurasi alat ukur, misalnya penggunaan thermometer batang serta layangan arus untuk mengukur suhu dan kecepatan arus.

\subsubsection{Uji Multikolinieritas}

Multikolinieritas adalah keadaan dimana antara dua variabel independen atau lebih pada model regresi terjadi hubungan linier yang sempurna atau mendekati sempurna. Untuk melihat ada tidaknya masalah multikolinieritas, yaitu dengan melihat nilai Tolerance dan VIF. Hasil uji regresi berganda pada kolom Collinearity Statistics diketahui bahwa nilai Tolerance dari kelima variable independen lebih dari 0.1 dan nilai VIF kurang dari 10, jadi dapat disimpulkan bahwa dalam model regresi tidak terjadi masalah multikolinieritas.

\subsubsection{Uji F (Analisis Varians)}

Uji $F$ bertujuan untuk melihat apakah ada pengaruh yang diberikan oleh faktor oseanografi terhadap nilai hasil tangkapan yellowfin tuna. Pengaruh yang dimaksud dalam uji $\mathrm{F}$ ini adalah pengaruh yang diberikan secara bersama-sama oleh variabel X (parameter Oseanografi) terhadap satu variabel Y (hasil tangkapan yellowfin tuna).

Hasil uji $F$ dapat dilihat kelima faktor oseanografi pada model 1 secara bersama-sama berpengaruh nyata terhadap hasil yang tangkapan yellowfin tuna. Hal ini dapat lihat pada nilai signifikansi model 1 pada Tabel 1 adalah $0.000<$ 0.01 , dan $F_{\text {hitung }}$ lebih besar dari $F_{\text {tabel }}(8.23>$ 2.44), ini menunjukan bahwa parameter oseanografi diantaranya suhu permukaan laut (SPL), klorofil-a, kedalaman, salinitas serta kecepatan arus secara bersama-sama berpengaruh nyata terhadap hasil tangkapan yellowfin tuna, sehingga model ini dapat digunakan untuk meramalkan hasil tangkapan yellowfin tuna.

Persamaan di masukan dengan model persamaan adalah $\log \mathbf{Y}=\log a+\mathbf{b}_{1} \log \mathbf{X}_{1}+$ $b_{2} \log X_{2}+b_{3} \log X_{3}+b_{4} \log X_{4}+b_{5} \log X_{5}$, dengan Y (Hasil Tangkapan), $X_{1}$ (SPL), $\quad X_{2}$ (Klorofil-a), $X_{3}$ (Kedalaman), $X_{4}$ (Salinitas), $X_{5}$ (Kec. Arus).

Persamaan kemudian dianalisis untuk mendapatkan prediksi hasil tangkapan. Gambar 8 menunujukan hubungan antara prediksi tangkapan yellowfin tuna dari persamaan yang terbentuk (model 1) dan hasil tangkapan yang diperoleh di lapangan.

\subsubsection{Uji t (Analisis Koefisien Regresi)}

Uji t dilakukan untuk melihat pengaruh faktor oseanografi tersebut terhadap hasil tangkapan yellowfin tuna secara individual. Hasil uji t menunjukan bahwa secara individu pada model ketiga hanya faktor suhu permukaan laut (SPL), kedalaman dan kecepatan arus yang mempengaruhi hasil tangkapan secara signifikan. 
Dengan nilai probabilitas dari masing-masing parameter oseaografi tersebut adalah Suhu permukaan Laut/SPL $\left(\mathrm{X}_{1}\right)$ probabilitas $(\mathrm{Sig}) 0.02$ $<0.1$, kedalaman $\left(\mathrm{X}_{3}\right)$ probabilitas $(\mathrm{Sig}) 0.000<$ 0.1 dan kecepatan arus $\left(\mathrm{X}_{5}\right)$ dengan probabilitas
(Sig) $0.048<0.1$ (Tabel 2), sehingga dapat disimpulkan bahwa perubahan suhu permukaan laut/SPL $\left(\mathrm{X}_{1}\right)$, Kedalaman $\left(\mathrm{X}_{2}\right)$ dan Kecepatan arus $\left(\mathrm{X}_{3}\right)$ dapat berpengaruh nyata terhadap hasil tangkapan yellowfin tuna $(\mathrm{Y})$.

Tabel 1. Hasil Uji F Regresi Cobb-douglas dengan metode Backward

ANOVA(d)

\begin{tabular}{llrrrrr}
\hline \multicolumn{1}{c}{ Model } & & $\begin{array}{c}\text { Sum of } \\
\text { Squares }\end{array}$ & df & Mean Square & F & \multicolumn{1}{c}{ Sig. } \\
\hline 1 & Regression & 3,961 & 5 &, 792 & 8,238 &, $000(\mathrm{a})$ \\
& Residual & 11,828 & 123 &, 096 & & \\
& Total & 15,789 & 128 & & & \\
\hline
\end{tabular}

a Predictors: (Constant), Kec. Arus, Klorofil-a, Salinitas, Kedalaman, SPL

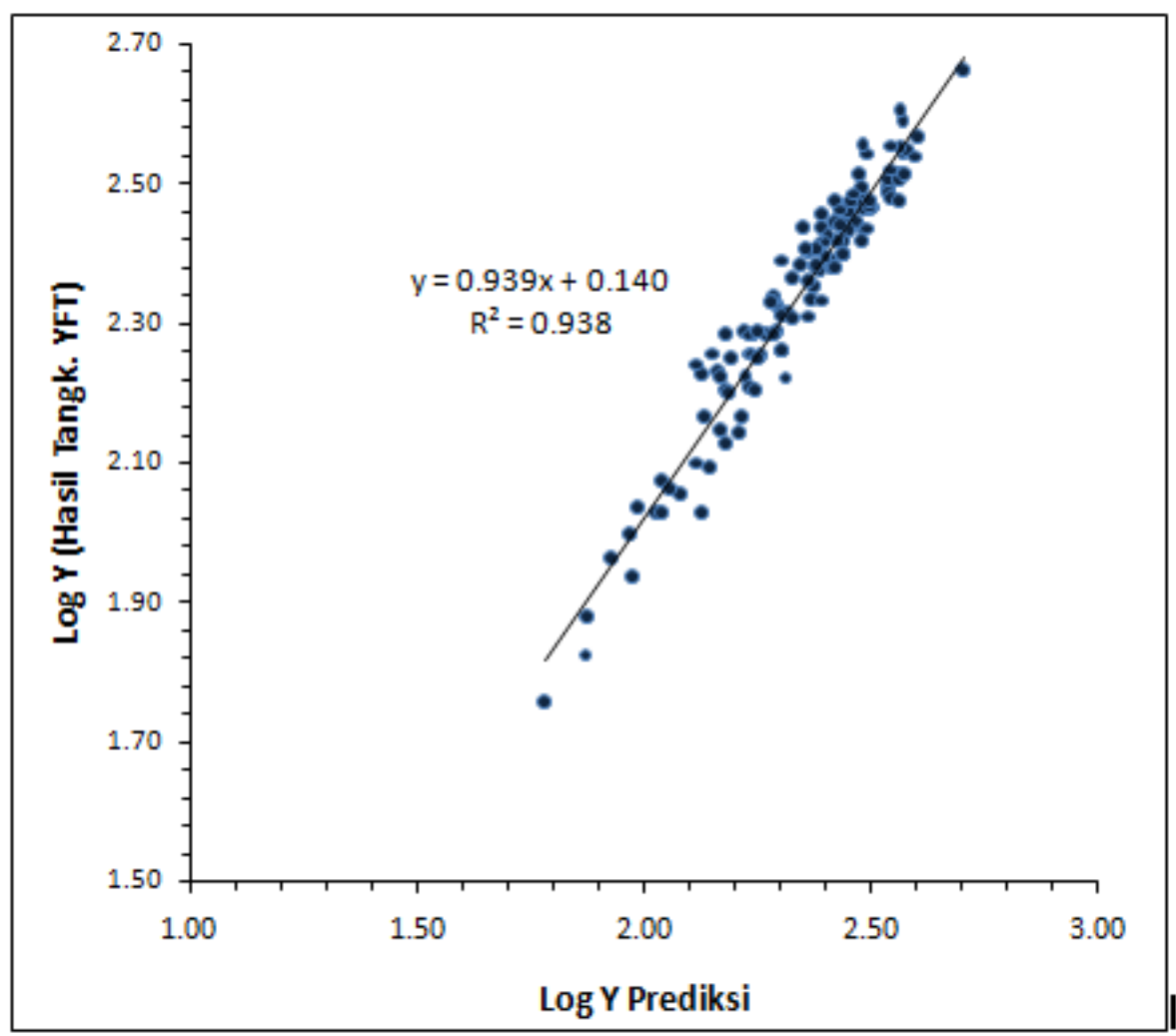

Gambar 8. Grafik Hubungan antara Hasil Tangkapan Lapangan dengan Tangkapan Prediksi.

Tabel 2. Hasil Uji t antara Variabel Independent dan Variabel Dependent

Coefficients(a)

\begin{tabular}{|c|c|c|c|c|c|c|}
\hline \multirow{2}{*}{ Model } & & \multicolumn{2}{|c|}{$\begin{array}{c}\text { Unstandardized } \\
\text { Coefficients }\end{array}$} & \multirow{2}{*}{$\begin{array}{c}\begin{array}{c}\text { Standardized } \\
\text { Coefficients }\end{array} \\
\text { Beta }\end{array}$} & \multirow{2}{*}{$t$} & \multirow{2}{*}{ Sig. } \\
\hline & & B & Std. Error & & & \\
\hline \multirow[t]{4}{*}{3} & (Constant) & 8,211 & 2,657 & & 3,090 &, 002 \\
\hline & SPL & $-5,302$ & 1,710 &,- 252 & $-3,101$ & ,002 \\
\hline & Kedalaman & 644 & 170 & ,306 & 3,790 & ,000 \\
\hline & Kec. Arus & 287 & 144 & 158 & 2,000 & ,048 \\
\hline
\end{tabular}




\subsubsection{Persamaan Hasil Regresi}

Tabel 3 dapat di interpretasikan sebagai berikut koefisien korelasi $(\mathrm{R})$ sebesar 0.485 , hal ini menunjukan bahwa hubungan antara hasil tangkapan dan parameter oseanografi yang diamati (SPL, kedalaman dan kec arus) sebesar $48.5 \%$. Koefisien determinasi (R Square) adalah 0.217 artinya $21.7 \%$ variabel yang terjadi terhadap hasil tangkapan disebabkan oleh variabel SPL, kedalaman dan Kec. Arus dan sisanya $78.3 \%$ di pengaruhi oleh faktor lain.

Faktor lain yang diduga berpengaruh adalah penggunaan umpan pada operasi penangkapan, dimana kecenderungan yellowfin tuna untuk memakan jenis umpan yang dipakai oleh nelayan pada umumnya tidak menentu, sehingga nelayan pada saat operasi penangkapan selalu membawa beberapa jenis umpan yang berbeda yaitu umpan hidup (ikan terbang, layang dan trigger), serta umpan buatan (model cumi, ikan terbang, gaya lambat serta ikan-ikan kecil). Pengaruh yang diberikan oleh umpan ini sangat besar sesuai dengan pendapat Sadhori (1985), bahwa umpan merupakan salah satu faktor yang sangat besar pengaruhnya terhadap keberhasilan dalam usaha penangkapan baik masalah jenis umpan, sifat umpan maupun cara ikan memakan umpan. Selain itu hasil penelitian Cayre et al (1993) dalam Watimury (1998), bahwa dalam suatu kelompok ikan cakalang dan madidihang (yellowfin tuna) tidak selalu dapat mengkonsumsi mangsa (prey) yang sama tetapi bagaimanapun dapat memiliki preperensi untuk ikan yang sama selama mereka mampu menangkapnya.

Tabel 3. Nilai koefisien Korelasi antara Variabel Independent dan Dependent.

Model Summary(d)

\begin{tabular}{ccccc}
\hline Model & $\mathbf{R}$ & R Square & $\begin{array}{c}\text { Adjusted R } \\
\text { Square }\end{array}$ & $\begin{array}{c}\text { Std. Error of the } \\
\text { Estimate }\end{array}$ \\
\hline 3 &, $485(\mathrm{c})$ &, 235 &, 217 &, 310776 \\
\hline $\begin{array}{l}\text { c Predictors: (Constant), Kec. Arus, Kedalaman, SPL) } \\
\text { d Dependent Variable: Hasil Tangkapan YFT }\end{array}$ & &
\end{tabular}

\subsubsection{Prediksi Model Regresi Cobb-Douglas}

Model terbaik yang didapatkan dari analisis regresi berganda dengan metode Backward untuk melihat hubungan parameter oseanografi dan hasil tangkapan yellowfin tuna adalah $\hat{Y}=8.211-5.302 X_{1}+0.644 X_{2}+$ $0.287 X_{3}$, dengan $X_{1}$ (Suhu Permukaan Laut/SPL $\left.\left({ }^{\circ} \mathrm{C}\right)\right), \quad \mathrm{X}_{2}$ (Kedalaman $\left.(\mathrm{m})\right)$ dan $\mathrm{X}_{3}$ (Kec. Arus $(\mathrm{m} / \mathrm{s}))$. Besarnya pengaruh yang diberikan oleh masing-masing parameter oseanografi terhadap hasil tangkapan yellowfin tuna dapat di ketahui dengan melihat koefisien determinasi dari masing-masing parameter oseanografi tersebut, dimana :

1. Pengaruh nyata yang diberikan oleh suhu permukaan laut, bernilai negatif dengan koefisien determinasi suhu permukaan laut $\left(\mathrm{X}_{1}\right)$ adalah $11.97 \%$, ini berarti bahwa setiap penurunan SPL $1{ }^{\circ} \mathrm{C}$ maka hasil tangkapan juga bertambah sebesar $1.197 \mathrm{Kg}$ dengan asumsi bahwa kedalaman dan kecepatan arus tetap.

2. Koefisien determinasi kedalaman $\left(X_{2}\right)$ adalah $14.36 \%$, ini berarti bahwa setiap pertambahan kedalaman $1 \mathrm{~m}$ maka hasil tangkapan juga bertambah sebesar $1.436 \mathrm{Kg}$ dengan asumsi bahwa SPL dan kecepatan arus tetap.
3. Koefisien determinasi Kecepatan Arus $\left(X_{3}\right)$ adalah $4.20 \%$, ini berarti bahwa setiap pertambahan kecepatan arus $1 \mathrm{~m} / \mathrm{s}$ maka hasil tangkapan juga bertambah sebesar $0.420 \mathrm{Kg}$ dengan asumsi bahwa SPL dan kedalaman.

\subsection{Hubungan Parameter Oseanografi dan Hasil Tangkapan Yellowfin Tuna}

Keberadaan suatu spesies ikan tertentu di suatu lokasi perairan tertentu sangat tergantung dengan kondisi parameter oseanografi. Respon sumberdaya ikan terhadap perubahan lingkungan dengan cara menghindar, menyebabkan sumberdaya ikan terdistribusi sesuai dengan kondisi lingkungan serta berdasarkan aktivitas yang di lakukan. Secara umum ikan akan memilih habitat yang lebih sesuai dengan kondisi oseanografi perairan, dengan demikian daerah potensi penangkapan ikan sangat di pengaruhi oleh parameter oseanografi perairan.

\subsubsection{Suhu Permukaan Laut/SPL}

Suhu perairan memiliki pengaruh yang bervariasi diantara berbagai jenis ikan, bahkan dalam satu jenis ikan suhu dapat memiliki pengaruh yang berbeda terhadap Laju Metabolisme Standar (Standard Metabolic Rates/SMR) dari ikan. Suhu perairan juga 
mempengaruhi pertumbuhan ikan, aktifitas dan ruaya, penyebaran, kelimpahan, penggerombolan, maturasi, fekunditas, pemijahan masa inkubasi dan penetesan telur serta kelulusan hidup larva ikan, oleh karena itu pengetahuan tentang suhu optimum ini akan bermanfaat dalam peramalan keberadaan kelompok ikan, sehingga dapat dengan mudah dilakukan penangkapan (Laevestu dan Hela, 1970). Dengan demikian yellowfin tuna akan memilih suhu yang sesuai dengan keperluan metabolisme. Suhu yang terlalu ekstrim yang tidak dapat di adaptasi oleh yellowfin tuna pada tahap kehidupan tertentu dapat menyebabkan terjadinya reaksi penghindaran terhadap daerah tersebut.

Parameter suhu mempunyai korelasi yang signifikan terhadap hasil tangkapan, ini dapat dilihat pada uji t terhadap nilai koefisien variabel suhu dengan nilai $0.02<0.1$. hubungan korelasi ini memberikan informasi bahwa kelimpahan yellowfin tuna di pengaruhi oleh SPL. Kondisi ini sejalan dengan pendapat Baskoro et al. (2005) bahwa fluktuasi suhu dan perubahan georafis sebagai faktor penting yang merangsang dan menentukan pengkonsentrasian serta pengelompokan ikan. Selanjutnya dikatakan pula bahwa suhu dapat mempengaruhi ikan dikarenakan suhu: (1) sebagai pengatur proses metabolisme (dapat mempengaruhi permintaan kebutuhan makanan dan tingkat penerimaan dan serta tingkat pertumbuhan), (2) sebagai pengatur aktifitas gerakan tubuh (kecepatan renang) dan (3) sebagai sistimulasi syaraf.

Hubungan yang signifikan antara SPL dan hasil tangkapan ikan yellowfin tuna diduga disebabkan karena yellowfin tuna pada umumnya merupakan predator yang selalu berada di lapisan permukaan pada siang hari untuk berburu mangsanya (Gradieff, 2003). Menurut Leavsetu dan Hela (1970), menyatakan bahwa yellowfin tuna merupakan jenis ikan pelagis yang dalam kelompok ruayanya akan muncul sedikit diatas lapisan termoklin pada siang hari dan akan beruaya ke lapisan permukaan pada sore hari. Pada malam hari akan menyebar dilapisan permukaan dan termoklin kemudian pada saat matahari terbit akan berada kembali diatas lapisan termoklin, selanjutnya dikatakan pula bahwa umumnya pengaruh suhu terhadap ikan adalah dalam proses metabolisme seperti pertumbuhan dan pengambilan makanan, aktivitas tubuh seperti kecepatan renang, serta rangsangan syaraf sehingga ikan sangat peka terhadap perubahan suhu walau hanya sebesar $0.003{ }^{\circ} \mathrm{C}$ Leavsetu dan Hela (1970).
Faktor lain yang diduga berkaitan dengan pengaruh SPL terhadap hasil tangkapan adalah pola adaptasi yang berkembang pada ikan yelllowfin tuna. Adaptasi yang berkembang pada jenis tuna adalah adanya mekanisme 'penukar panas vascular counter-current' yang memungkinkan tuna untuk mengembangkan inersia termal yang lebih efektif dibandingkan ikan pada ukuran yang sama (Neill et al. 1976; Stevens \& Neill 1978, diacu dalam Brill et al. 1999). Karena individu yang lebih besar memiliki inersia termal yang lebih berkembang maka laju penurunan suhu otot lebih lambat bila dibandingkan tuna yang lebih kecil. Dengan demikian tuna dewasa yang lebih besar mampu melakukan pergerakan vertikal yang lebih intensif dibandingkan tuna juvenil.

\subsubsection{Klorofil-a}

Hasil analisis statistik, diketahui bahwa parameter klorofil-a tidak mempunyai korelasi yang nyata terhadap hasil tangkapan yellowfin tuna. Hal ini dapat dilihat pada nilai signifikansi pada uji $\mathrm{t}$, dimana nilai uji $\mathrm{t}$ untuk klorofil-a $0.269>0.1$, selain itu variabel konsentrasi klorofil-a ini telah dikeluarkan dari persamaan regresi dengan menggunakan model regresi Cobb-douglas dengan metode backward.

Pengaruh yang tidak nyata antara konsentrasi klorofil-a dengan hasil tangkapan yellowfin tuna diduga karena keberadaan ikan yellowfin tuna pada lapisan permukaan lebih dipengaruhi oleh pola asosiasinya dengan lumbalumba (Stenella sp). Asosiasi ikan yellowfin tuna dengan lumba-lumba ini sering digunakan sebagai indikator daerah penangkapan oleh nelayan. Sebagai hewan yang bernafas dengan udara bebas, lumba-lumba lebih mudah untuk diamati sehubungan dengan aktivitas mereka di permukaan. Model komposisi school ikan yellowfin tuna yang berasosiasi dengan lumbalumba menunjukkan bahwa ikan yellowfin tuna dengan ukuran relatif besarlah yang ditemukan berasosiasi dengan lumba-lumba yaitu panjang total $55-125 \mathrm{~cm}$ (Edwards, 1992). Selanjutnya berdasarkan model bioenergetik komparatif dari ikan yellowfin tuna dan lumba-lumba terdapat kecenderungan ikan yelllowfin tuna berenang mengikuti lumba-lumba. Kekuatan asosiasi ini kemungkinan berkaitan pula dengan kondisi oseanografis yang mempengaruhi distribusi dan kelimpahan ikan mangsa.

Pengaruh yang tidak nyata ini juga diduga karena nilai rerata konsentrasi klorofil-a pada lapisan permukaan perairan laut Banda lebih kecil dari $0.2 \mathrm{mg} / \mathrm{m}^{3}$. Menurut Loukos et al. 
(2003) bahwa fitoplankton bukan merupakan makanan alami tuna tetapi sebagai rantai dasar makanan tuna. Produksi tersier dan sekunder membuat makanan tuna (forage) bergantung pada produktivitas primer fitoplankton. Perkembangan makanan tuna dari produktivitas primer membutuhkan waktu beberapa minggu untuk crustaceans kecil sampai beberapa bulan (time $l e g$ ) untuk ikan pelagis kecil.

Selama pergerakan acak organisme tersebut oleh surkulasi oseanik, maka distribusi makanan ini di ikuti oleh tuna, jika pengetahuan ini dikaitkan dengan hasil analisis statistik antara konsentrasi klorofil-a dan jumlah hasil tangkapan yellowfin tuna yang menunjukan pengaruh tidak nyata, maka hal ini diduga disebabkan karena kehadiran yellowfin tuna bukan sebagai ikan yang mengkonsumsi klorofil-a (phytoplankton) tetapi merupakan pemakan ikan pelagis kecil yang berada pada lokasi tempat berkumpulnya ikan pelagis yang memangsa zooplankton dan phytoplankton sebagai konsumen tingkat I dan produsen. Konsentrasi yellowfin tuna pada makanan ini dapat menggambarkan secara jelas pula bahwa rata-rata konsentrasi klorofil-a pada lapisan permukaan lebih kecil sehingga nilai konsentrasi ini tidak berpengaruh nyata terhadap kehadiran, tetapi sesuai dengan hasil penelitian Syah (2009), maka konsentrasi klorofil-a pada lapisan kedalaman $40-80 \mathrm{~m}$ dengan nilai konsentrasi klorofil-a diatas $0.2 \mathrm{mg} / \mathrm{m}^{3}$ dapat diduga merupakan indikasi keberadaan yellowfin tuna di perairan laut Banda.

\subsubsection{Kedalaman}

Hasil analsis statistik dengan metode backward menunjukan bahwa faktor kedalaman merupakan salah satu variabel yang berpengaruh nyata terhadap hasil tangkapan yellowfin tuna dengan nilai signifikansi 0.000 dimana nilai ini lebih kecil dari 0.1, dengan koefisien korelasi sebesar 0.379. fakor kedalaman ini secara bersama-sama dengan SPL dan Kecepatan arus berpengaruh nyata terhadap hasil tangkapan yellowfin tuna.

Hubungan anatara kedalaman perairan dan jumlah hasil tangkapan ini belum banyak diketahui. Beberapa penelitian di luar negeri diantaranya oleh Cayre dan Marsac (1993) dalam Zhu, et al (2009) menyatakan bahwa identifikasi karakteristik perairan dengan distribusi vertikal ikan umumnya belum jelas tetapi faktor suhu dan konsentrasi oksigen terlarut dapat menjelaskan distribusi vertikal dari yellowfin tuna. Hays (2003), menjelaskan menyatakan bahwa gerakan vertikal yellowfin tuna pengaruhnya dengan kedalaman perairan diperkirakan terutama terjadi untuk menghindari predator visual yang merupakan pemburu efektif dalam zona fotik.

\subsubsection{Salinitas}

Hasil analisis statistik faktor salinitas di keluarkan dari model persaman regresi, hal ini dapat dilihat pada nilai uji t yaitu sebesar 1.143 dengan nilai signifikansi 0.255 atau lebih besar dari $0.1(0.255>0.1)$, besarnya nilai signifikansi menunjukan bahwa faktor salinitas tidak berpengaruh nyata terhadap hasil tangkapan yellowfin tuna.

Kecilnya nilai korelasi antara hasil tangkapan yellowfin tuna dan salinitas $(r=0.056)$ diduga karena yellowfin tuna merupakan jenis ikan pelagis yang hidup pada daerah diatas lapisan termoklin yang cenderung homogen sehingga fluktuasi salinitas pada daerah ini sangat kecil. Selain itu pada perairan tropis umumnya fluktuasi salinitas sangat kecil dan salinitas juga tidak tampak sebagai faktor yang mempengaruhi distribusi tuna tetapi mencirikan massa air yang dapat membantu mengenal daerah penangkapan yang lebih potensial (Stequert dan Marsac (1989) dalam Waas (2004)).

\subsubsection{Kecepatan Arus}

Hasil analisis statistik menunjukan bahwa nilai uji $\mathrm{t}$ dari kecepatan arus adalah 2.000 dengan nilai signifikansinya $0.048<0.1$, artinya faktor kecepatan arus secara statistik berpengaruh nyata terhadap jumlah hasil tangkapan. Pengaruh nyata yang terjadi antara kecepatan arus dan hasil tangkapan yellowfin tuna ini diduga karena ikan tersebut akan cenderung berada pada daerah yang berarus untuk dapat mendapatkan makanan. Hal ini sesuai dengan pendapat Laevestu (1981), mengemukakan bahwa arus merupakan salah satu aspek penting dalam kaitannya dengan distribusi ikan, sehingga dapat mempengaruhi distribusi ikan dewasa secara langsung maupun tidak langsung dan pengaruh secara tidak langsung ini disebabkan oleh agregasi makanan ikan pada lokasi tertentu. Mekanisme arus ini mejawab mengapa tuna di temukan pada perairan yang berarus karena aliran arus akan membawa agregat makanan hal tersebut berpengaruh terhadap ikan tuna dimana ikan tuna akan beruaya mengikuti sumber makanan (Lehodey et al., 2003).

Laevestu dan Hayes (1981), menyatakan bahwa daerah tangkapan yang baik terletak pada daerah batas arus atau daerah upwelling dan divergen. Lebih lanjut dikatakan bahwa daerah tangkapan tuna terbaik berada pada zona yang berhubungan dengan arus yang sama. Menurut 
Reddy (1993) arus konvergen membawa agregat makanan (forage) organisme dan juga ikan kecil. Dalam batas arus divergen nutrient dari lapisan dalam diangkat ke permukaan dan menyebabkan tingginya produksi bahan organik dan disertai oleh konsentrasi ikan.

\section{KESIMPULAN DAN SARAN}

Hasil analisis parameter oseanografi diketahui bahwa dari lima parameter oseanografi secara bersama-sama berpengaruh nyata terhadap hasil tangkapan yellowfin tuna ini dapata dilihat pada hasil Uji $F$ dengan nilai signifikansi 0.000 $\left\langle 0.01\right.$, dan $\mathrm{F}_{\text {hitung }}$ lebih besar dari $\mathrm{F}_{\text {tabel }}$ (8.23 > 2.44), Hasil uji t menunjukan bahwa secara individual terdapat tiga dari lima faktor
Oseanografi yang berpengaruh nyata terhadap hasil tangkapan ikan yellowfin tuna, diantaranya suhu permukaan laut (SPL), kedalaman dan kecepatan arus.

Nilai koefisien determinasi antara faktor oseanografi dan hasil tangkapan yellowfin tuna adalah $21.7 \%$, artinya masih ada pengaruh dari faktor lain sebesar $78.3 \%$, dengan melihat besarnya nilai faktor lain ini, maka perlu dilakukan penelitian lanjutan tentang faktor apa saja yang berpengaruh selain lima faktor oseanografi tersebut sehingga dapat menjamin data penelitian untuk, memprediksi potensi perikanan tuna khususnya yellowfin tuna di laut Banda pada bulan-bulan selanjutnya.

\section{DAFTAR PUSTAKA}

Baskoro, M. S dan Effendy, A., 2005. Tingkah Laku Ikan : Hubungannya dengan Metode Pengoperasian Alat Tangkap Ikan. Departemen Pemanfaatan Suberdaya Perikanan. IPB. Bogor.

Dinas Kalutan dan Perikanan, 2008. Laporan Produksi Perikanan Tangkap Provinsi Maluku. DKPAmbon.

Edwards EF., 1992. Energetics of Associateds Tunas and Dolphins in The Eastern Tropical Pasific Ocean: A Basis For the Bond. Fish Bull 90 : 678-690

FAO, 2003. FAO Species Catalogue Vol. 2 Scombrids of The World An Annotated And llustratted Cataloque of Tunas, Mackerel, Bonitas and Related Species Known to Date. Rome. UN.

Gunarso, W. 1985. Tingkah Laku Ikan dalam Hubungannya dengan Alat, Metoda dan Teknik Penangkapan. Diktat Kuliah Jurusan Pemanfaatan Sumberdaya Perikanan. Fakultas Perikanan Institut Pertanian Bogor. Bogor.

Gower, J.F.R. 1972., Opportunities and Problems in Satelite Measurement of the Distribution of Phytoplankton in Eutrophic Coastal Waters. Aust. J. Mar. Fresw. Res., 189, 40,559-569.

Gradieff S., 2003. Yellowfin tuna. http://www.flmnh.ufl.edu. [diakses 12 Juni 2011].

Laevastu, T and M. L Hayes. 1980. Fisheries Oceanography and Ecology. London: Fishing News Books Ltd. 119p.

Laevastu T, dan I. Hela., 1970. Fisheries Oceanography. London: Fishing News 238 hlm.

Laevastu, T. dan I. Hela., 1980. Fisheries Oceanography. New Ocean Environmental Series. Fishing News (Books) Ltd. 110 Fleet. Street, London, E.C. 4.: 238 pp.

Lehoday, P. 2002. SEPODYM Development and Application to Skipjack Population and Fisheries. $15^{\text {th }}$ SCTB, Hawai, 22-27 ${ }^{\text {th }}$ July 2002, Oseanic Fisheries Programe. Secretariat of The Pasific Community, Noume, New Caledonia. Working Paper SKJ. http//:www.spc.int/Oceanfish/SCTB/SCTB15/SKJ 5.pdf.

LON-LIPI., 1992. Penelitian Potensi Ikan Pelagis dan Karakteristik Lingkungan Perairan Maluku dan Irian Jaya. Pusat Penelitian dan Pengembangan Oseanologi. Lembaga Ilmu Pengetahuan Indonesia. Jakarta.

Nugraha, B., 2009. Studi Tentang Genetika Populasi Ikan Tuna Mata Besar (Thunnus albacares) Hasil Tangkapan Long Line yang Didaratkan di Benoa. Bogor. Institut Pertanian Bogor.

Nakamura, H. 1969. Tuna (Ditribution \& Migration). Printed in Great Britain by The Whitefrians Press Ltd. London and Tonbrigde.

Nontji, A. 1993. Laut Nusantara. Edisi Kedua. Penerbit PT. Djambatan. Jakarta.

Paena M. 2002. Pemanfaatan Teknik Penginderaan Jauh dan Sistem Imformasi Geografi untuk Menentukan Daerah Penangkapan Ikan Pelagis Kecil di Perairan Selat Makassar. Thesis S2 Universitas Gajah Mada. UGM Yogyakarta. (tidak di publikasikan) 
Priyatno, D., 2009. SPSS (Analisis Korelasi, Regresi, dan Multivariate). Cetakan Pertama Penerbit Gava Media. Yogyakarta.

Pusat Riset Perikanan Tangkap., 2001. Pengkajian Stok Ikan di Perairan Indonesia. Badan Riset Kelautan dan Perikanan-DKP dan Pusat Penelitian dan Pengembangan Oseanologi-LIPI. Jakarta.

Reddy, M. P. M., 1993. Influence of The Oceanographic Parameter on The Abudance of Fish Catch. In International Workshop on Apllication of Satelit Remote Sensing for identifying and Forescasting Potential Fishing Zone in Developing Countrys. India.

Santosa, S. et al. 2005. Menggunakan SPSS untuk Statistik Parametrik. Seri Solusi Bisnis berbasis Tl. PT. Elex Media Komputindo. Kelompok Gramedia. Jakarta.

Scheafer M. Kurt., Danial W. Fuller., Barbara A. Block., 2007. Movments, Behaviour and Habitat Utilization of Yellowfin tuna (Thunnus albacares) in The Norheast Pasific Ocean, Ascertained Through Archival Tag Data. Journal Mar Biol 152:503 - 525.

Supadiningsih, C. N. dan Rosana, N., 2004. Penentuan Fishing Ground Tuna dan Cakalang Dengan Teknologi Penginderaan Jauh. Disampaikan pada Pertemuan Ilmiah Tahunan I Teknik Geodasi. ITS-Surabaya.

Supangat, A., 2007. Statistika : dalam Kajian Deskriptif, Inferensi dan Nonparametrik. Edisi Pertama, cetakan ke-2. Penerbit Prenada Media Group. Jakarta. Indonesia.

Syah. Ach. F., 2009. Distribusi Vertikal klorofil-a di Perairan Laut Banda Berdasarkan Neural Network. (Thesis) [tidak dipublikasikan]. Bogor. Teknologi Kelautan Institut Pertanian Bogor.

Tadjudah M., 2005. Analisis Daerah Penangkapan Ikan Cakalang (Katsuwonus pelamis) dan Madidihang (Thunnus albacares) Dengan Menggunakan Data Citra Satelit di Perairan Kabupaten Wakatobi Sulawesi Tenggara. (Thesis) [tidak dipublikasikan]. Bogor. Teknologi Kelautan Institut Pertanian Bogor.

Uktolseja, J. C. B, et al., 1991. Estimated Growth Parameters and Migration of Skipjack Tuna dan Tuna Likes in the Estearn Indonesia Water Trough Tagging Experiments. Jurnal Penelitian Perikanan Laut No. 43 Tahun 1987. Balai Penelitian Perikanan Laut, Jakarta.

Waas, H. J. D., 2004. Analisis Daerah Potensial Penangkapan Cakalang (Katsuwonus pelamis) dan Madidihang (Thunnus albacares) di Perairan Utara Papua, Pasifik Barat. (Thesis) [tidak dipublikasikan]. Bogor. Teknologi Kelautan Institut Pertanian Bogor.

Watimury, J. J., 1998. Penentuan Zona Konsentrasi Ikan Cakalang dan Madidihang (yellowfin tuna) di Perairan Ambon dan Sekitarnya Menggunakan Data NOAA/AVHRR dan Sistem INformasi Geografis. (Thesis) [Tidak di Publikasikan]. Program Studi Penginderaan Jauh Jurusan Ilmu-Ilmu Matematika dan Ilmu Pengetahuan Alam. UGM Yogyakarta.

Wolpole, R.A., 2000. Pengantar Statistika : Edisi 3. PT. Gramedia Pustaka Utama. Jakarta.

Zainuddin, M., Safruddin, dan Ismail. 2007. Pendugaan Potensi Sumberdaya Laut dan Migrasi Ikan Pelagis Kecil di Perairan Sekitar Jeneponto. Laporan Hasil Penelitian. Laboratorium Sistem Imformasi Perikanan Tangkap. Program Studi Pemanfaatan Sumberdaya Perikanan. Jurusan Perikanan. Fakultas llmu Kelautan dan Perikanan. Universitas Hasanuddin Makassar.

Zhu., J., Liuxiong, X., Xiaojie, D., Xinjung, C., Yong, C. 2009. Vertical Distribution of 17 Pelagic Fish Species In The Longline Fisheries IN The Eastern Pacific Ocean. Document Sarm-1014lb. Inter-american Tropical Tuna Comision $10^{\mathrm{TH}}$ Stock Assesment Review Metting La Jola. California (USA) 12 - 15 May 2009. 